\title{
ANALISIS PERANGKAT PEMBELAJARAN GURU PENDIDIKAN AGAMA ISLAM BERDASARKAN KURIKULUM 2013 DI SMP NEGERI 1 PERCUT SEI TUAN DELI SERDANG
}

\author{
Nurainun* \\ *Guru SMP 1 Percut Sei Tuan Kab. Deli Serdang
}

\begin{abstract}
The purpose of this study was to determine: (1) Suitability of 2013 Curriculum Annual Program Preparation, (2) Suitability of Compilation of the 2013 Curriculum Semester Program. (3) Appropriate components of the Learning Implementation Plan (RPP) based on Permendikbud No.22 2016. The approach used in this study is a qualitative approach The data analysis technique used is data collection, data reduction and data presentation conclusions. The technique of guaranteeing the validity of the data is done by checking trust, checking examination and checking dependency. The results of the study can be concluded that the results of the Analysis of Suitability of Annual Programming, Semester Program, and Learning Implementation Plan can be categorized as "In Accordance" because the results are obtained based on the scores of the Annual Program, Semester Program and Learning Implementation Plan (RPP) compiled by the teacher Islamic religious education in SMP Negeri 1 Percut Sei Tuan Deli Serdang.
\end{abstract}

Key Word: Management Devices, Curriculum 2013

\section{PENDAHULUAN}

Analisis perangkat pembelajaran yang pertama adalah program tahunan, yang merupakan rencana penetapan alokasi waktu satu tahun untuk mencapai tujuan (SK dan KD) yang telah ditetapkan. Penetapan alokasi waktu diperlukan agar seluruh kompetensi dasar yang ada dalam kurikulum seluruhnya dapat dicapai oleh siswa. Program tahunan perlu dipersiapkan dan dikembangkan oleh guru sebelum tahun pelajaran, karena merupakan pedoman bagi pengembangan program-program berikutnya, yakni program semester, silabus, dan Rencana Pelaksanaan pembelajaran (RPP).

Program Semester merupakan penjabaran dari program tahunan yang berisi hal-hal yang ingin dicapai pada semester tersebut. Program semester adalah rumusan kegiatan belajar mengajar untuk satu semester yang kegiatannya dibuat berdasarkan pertimbangan alokasi waktu yang 
tersedia, jumlah pokok bahasan yang ada dalam semester tersebut dan frekuensi ujian yang disesuaikan dengan kalender pendidikan. Program Semester tidak bisa disusun sebelum tersusun program tahunan. Oleh karena itu, perlunya analisis langkah-langkah penyusunan Program Tahunan dan Program semester.

Berdasarkan Permendikbud No.22 Tahun 2016 tentang Standar Proses Pendidikan Dasar dan Menengah bahwa perencanaan pembelajaran dirancang dalam bentuk silabus dan RPP yang mengacu pada standar isi atau perencanaan pembelajaran meliputi penyusunan Rencana Pelaksanaan Pembelajaran, penyiapan media, sumber perangkat penilaian dan skenario pembelajaran dan disesuaikan dengan pendekatan pembelajaran yang digunakan. tujuannya agar pembelajaran berlangsung secara interkatif, inspiratif dan menyenangkan.

Pada Kurikulum 2013, guru tidak dibebani lagi untuk menyusun Silabus, tugas tersebut sudah diambil alih oleh pemerintah. Dan dari silabus yang sudah disusun oleh pemerintah, guru hanya tinggal menjabarkannya kedalam Rencana Pelaksanaan Pembelajaran (RPP). Meski tidak lagi direpotkan dengan membuat silabus sendiri, guru tetap saja dituntut untuk dapat memahami seluruh pesan dan makna yang terkandung dalam silabus, terutama untuk kepentingan pembelajaran.

Penyusunan Rencana Pelaksanaan Pembelajaran pada kurikulum 2013 masih tetap menjadi kewenangan dari guru yang bersangkutan, yaitu dengan berusaha mengembangkan dari buku dan silabus yang telah disiapkan pemerintah. Recana Pelaksanaan Pembelajaran (RPP) yang merupakan perangkat pembelajaran yang dulu dikenal dengan istilah satuan pelajaran (satpel), identik dengan rencana pelajaran (Lesson Plan), dan strategi pembelajaran.

Menurut Widyastono (2007:1041). Rencana Pelaksanaan Pembelajaran memuat Kompetensi Inti (KI), Kompetensi Dasar (KD), indikator yang ingin dicapai, materi yang akan dipelajari, langkah pembelajaran, media pembelajaran, dan sumber belajar serta penilaian (Susetya, 2017:134).

Rencana pelaksanaan pembelajaran berfungsi sebagai acuan untuk melaksanakan proses belajar mengajar di kelas agar lebih efektif dan efisien. Oleh karena itu, penting bagi guru pendidikan agama islam untuk merencanakan apa yang ingin diajarkannya dalam sebuah rencana pelaksanaan pembelajaran (RPP). Keberadaan RPP menjadi salah satu tolak ukur kompetensi pedagogik seorang guru, yang diartikan bahwa kompetensi pedagogik adalah kemampuan mengelola pembelajaran 
peserta didik yang minimal meliputi pemahaman wawasan dan landasan pendidikan, pengembangan kurikulum/silabus, pemanfaatan teknologi pembelajaran, pemahaman peserta didik, perencanaan pembelajaran, pelaksanaan pembelajaran yang mendidik dan dialogis, evaluasi proses dan hasil belajar dan pengembangan peserta didik untuk mengaktualisasikan berbagai potensi yang dimiliki.

\section{KAJIAN TEORETIS}

Perangkat pembelajaran merupakan hal yang harus disiapkan oleh seorang guru sebelum melaksanakan pembelajaran. Dalam Kamus Besar Bahasa Indonesia (2007:17) perangkat adalah alat atau perlengkapan, sedangkan pembelajaran adalah proses atau cara menjadikan orang belajar.

Tugas guru sebelum mengajar seharusnya ia mempersiapkan diri untuk menyiapkan segala sesuatu untuk kegiatan pembelajaran. Seorang guru sebelum mengajar perlu mempersiapkan perangkat pembelajaran. Namun dalam hal tersebut, guru harus memiliki Kompetensi atau kemampuan melaksanakan sesuatu yang diperolehnya melalui pembelajaran. Hal ini harus dilakukan kerena pembelajaran merupakan tugas guru yang pertama dan utama, sehingga sudah sepatutnya direncanakan dan dilaksanakan dengan sebaik-baiknya.

Antonius (2016:5) meenjelaskan penyusunan perangkat pembelajaran berupa: Pembuatan Analisis Waktu, Penyusunan Program Tahunan dan Program Semester, Penyusunan Rencana Pelaksanaan Pembelajaran (RPP), Menyajikan Program Pembelajaran, Melaksanakan Evaluasi Belajar, Melaksanakan Analisis Hasil Evaluasi Belajar, serta Melaksanakan Program Perbaikan dan Pengayaan.

Trianto (2009:201) menjelaskan bahwa perangkat yang digunakan dalam proses pembelajaran disebut dengan perangkat pembelajaran. Perangkat pembelajaran yang diperlukan dalam mengelola proses belajar mengajar dapat berupa: silabus, Rencana Pelaksanaan Pembelajaran (RPP), Lembar Kegiatan siswa (LKS), Instrumen Evaluasi atau Tes Hasil Belajar (THB), Media pembelajaran, serta buku ajar siswa.

Marimba (2001:23) menjelaskan Pendidikan Agama Islam adalah bimbingan jasmani dan rohani berdasarkan hukum-hukum agama Islam menuju kepada terbentuknya kepribadian utama menurut ukuran-ukuran Islam. Sedangkan menurut Muhaimin (2004:6) Pendidikan Islam adalah pendidikan yang diselenggarakan atas dasar hasrat, motivasi, dan 
semangat untuk memanifestasikan nilai-nilai Islam, baik nilai-nilai ketuhanan maupun nilai-nilai kemanusiaan.

Tjuan pendidikan Islam menurut al-Abrasyi (1984:10) adalah terbentuknya ahlak atau budi pekerti, mempersiapkan kehidupan dunia dan akhirat membentuk pribadi yang utuh sehat jasmani dan rohani, menumbuhkan ruh ilmiah sehingga memungkinkan peserta didik mengkaji ilmu dan menyiapkan peserta didik agar mempunyai profesi tertentu sehingga dapat melaksnakan tugas dunia dengan baik.

Langgulung (1987:178) tujuan pendidikan Islam harus mampu mengakomodasi tiga fungsi utama dari agama, yaitu fungsi spiritual yang berkaitan dengan akidah dan iman, funsi psikologi yang berkaitan dengan tingakah laku invidual termasuk nilai-nilai akhlak yang menyangkut derajat manusia menjadi lebih sempurna, dan fungsi social yang berkaitan dengan atura-aturan antara manusia satu dengan manusia lain dan dengan masyarakat dimana masing-masing bertanggungjawab untuk menyusun masyarakat yang harmonis dan seimbang. Rumusan tujuan pendidikan Islam akan tepat apabila mempertimbangkan subjek dan objek pendidikan itu sendiri yakni manusia.

Majid (2004:130) berpendapat bahwa Pendidikan agama Islam bertujuan untuk menumbuhkan dan meningkatkan keimanan melalui pemberian dan pemupukan pengetahuan, penghayatan, serta pengalaman peserta didik, tentang agama Islam sehingga menjadi manusia muslim yang terus berkembang dalam hal keimanan, ketaqwaannya, bangsa dan bernugara, serta untuk melanjutkan padajenjang pendidikan yang lebih tinggi.

Undang-Undang Nomor 20 Tahun 2013 tentang Sistem Pendidikan Nasional menyebutkan bahwa kurikulum adalah seperangkat rencana dan pengaturan mengenai tujuan, isi, dan bahan pelajaran serta cara yang digunakan sebagai pedoman penyelenggaraan kegiatan pembelajaran untuk mencapai tujuan pendidikan tertentu. Mulyasa (2013:7) meenjelaskan Kurikulum 2013 lebih ditekankan pada pendidikan karakter, terutama pada tingkat dasar, yang akan menjadi pondasi bagi tingkat berikutnya. Melalui pengembangan kurikulum 2013 yang berbasis karakter dan kompetensi, kita berharap bangsa ini menjadi bangsa yang bermartabat, dan masyarakatnya memiliki nilai tambah (added value), dan nilai jual yang bisa ditawarkan kepada orang lain di dunia, sehingga kita bisa bersaing, bersanding dan bahkan bertanding dengan bangsa-bangsa lain dalam pencaturan global. Hal ini di mungkinkan, kalau implementasi 
kurikulum 2013 betul-betul dapat menghasilkan insan yang produktif, kreatif, inovatif, dan berkarakter.

\section{METODOLOGI PENELITIAN}

Penelitian ini dilaksanakan di SMP Negeri 1 Percut Sei Tuan. Pendekatan penelitian ini menggunakan metode kualitatif. Sumber data utama (primer), diperoleh dan dikumpulkan secara langsung dari informan melalui pengamatan, catatan lapangan dan interview dari Kepala Sekolah, Guru PAI dan peserta didik SMP Negeri 1 Percut Sei Tuan. Sumber data tambahan (skunder), yaitu data yang dikumpulkan, diolah, disajikan oleh pihak lain yang biasanya dari publikasi atau jurnal. Data sekunder adalah data yang sudah diolah dalam bentuk naskah tertulis atau dokumen berupa sejarah singkat sekolah atau profil sekolah, visi misi madrasah, Struktur Organisasi dan lain sebaginya. Teknik pengumpulan data terdapat empat macam teknik pengumpulan data, yaitu observasi, wawancara, dan dokumentasi. Prosedur pelaksanaan penelitian dilakukan dengan cara mereduksi data, menyajikan data dan membuat kesimpulan proses, analisis ini berlangsung selama penelitian ini berlangsung. Selanjutnyaa teknik keabsahan data adalah sebagai berikut: pengujian kredibilitas (kepercayaan), transferabilitas (keterlibatan), dependabilitas (kebergantungan), dan konfirmabilitas (kepastian) yang terkait dengan proses pengumpulan dan analisis data.

\section{HASIL PENELITIAN DAN PEMBAHASAN}

Deskripsi tentang perangkat pembelajaran Pendidikan Agama Islam diperoleh melalui hasil observasi. Selain itu, ada pendapat-pendapat yang diperoleh dari informan melalui wawancara dengan menjawab beberapa pertanyaan maupun pernyataan untuk membawa informasi yang tepat dan akurat. Hal ini bertujuan untuk menjawab berbagai permasalahan yang berhubungan dengan perangkat pembelajaran.

Berdasarkan hasil wawancara penulis terhadap guru-guru pendidikan agama islam, sebagaimana pendapat yang dikemukakan oleh Drs. Ali Nurdin, MA yang menyatakan bahwa: "Perangkat Pembelajaran adalah perlengkapan yang harus disiapkan oleh guru untuk melakukan proses pembelajaran, perangkat pembelajaran berupa: Kelender Pendidikan, Perhitungan Minggu Efektif, Jurnal Agenda guru, Program Tahunan, Program Semester, Kriteria Ketuntasan Belajar Minimal, Silabus, Sistem Penilaian Hasil Belajar, Rencana Pelaksanaan Pembelajaran (RPP), 
Media Pembelajaran, Daftar Nilai siswa dan Absensi". (Sumber data: Guru PAI, Tgl: 25 februari 2019).

Dari Pernyataan diatas bahwa Perangkat Pembelajaran menurut pendapat Drs. Ali Nurdin, MA ada sebelas macam perangkat pembelajaran yang harus disiapkan oleh guru sebelum melakukan proses pembelajaran. Sementara Sarmidi, S.Ag menyatakan bahwa: "Adapun perangkat Pembelajaran yang harus disiapkan oleh guru adalah: Perhitungan Minggu Efektif, Program Tahunan, Program Semester, Kriteria Ketuntasan Belajar Minimal, Silabus, Rencana Pelaksanaan Pembelajaran (RPP), Media Pembelajaran, Penilaian Hasil Belajar, Program Perbaikan dan Pengayaan". (Sumber data: Guru PAI, Tgl: 25 februari 2019).

Senada yang disampaikan oleh Siti Hadijah, S.Pd.I bahwa: "Perangkat Pembelajaran berupa: Perhitungan Minggu Efektif, Program Tahunan, Program Semester, Silabus, Rencana Pelaksanaan Pembelajaran (RPP), Media Pembelajaran, Penilaian Hasil Belajar, Program Perbaikan dan Pengayaan". (Sumber data: Guru PAI, Tgl: 4 maret 2019).

Berdasarkan Hasil Wawancara dengan guru-guru agama islam SMP Negeri 1 percut Sei Tuan dapat disimpulkan bahwa Pendapat guru tentang perangkat pembelajaran berbeda-beda, Menurut pendapat Drs. Ali Nurdin, MA ada sebelas perangkat pembelajaran, dan menurut pendapat Sarmidi, S.Ag ada sembilan perangkat pembelajaran, sedangkan menurut pendapat Siti Hadijah, S.Pd.I ada delapan perangkat pembelajaran. Namun meskipun berbeda tetapi masih ada persamaan pendapat tentang perangkat pembelajaran, diantaranya: Perhitungan Minggu Efektif, Program Tahunan, Program Semester, Silabus, Rencana Pelaksanaan Pembelajaran (RPP), Media Pembelajaran, Penilaian Hasil Belajar.

Berdasarkan Hasil Observasi, Peneliti juga telah melihat bukti-bukti perangkat pembelajaran yang ada pada guru Pendidikan agama islam disekolah tersebut dengan mengambil dokumentasi berupa: Perhitungan Minggu Efektif, Program Tahunan, Program Semester, Silabus, Rencana Pelaksanaan Pembelajaran (RPP), Media Pembelajaran dan Penilaian Hasil Belajar berupa Raport siswa. Namun, Peneliti hanya menganalisis Program Tahunan, Program Semester, dan Rencana Pelaksanaan Pembelajaran. karena untuk perhitungan minggu efektif sudah dicantumkan kedalam program tahunan dan program semester, sedangkan silabus sudah disusun oleh pemerintah, kemudian untuk 
Media pembelajaran dan penilaian hasil belajar sudah tercantum kedalam Rencana Pelaksanaan Pembelajaran (RPP).

Program tahunan merupakan program umum setiap mata pelajaran untuk setiap kelas, yang dikembangkan oleh guru mata pelajaran yang bersangkutan. Program ini perlu dipersiapkan dan disusun oleh guru sebelum tahun ajaran. Sebagaimana pendapat yang dikemukakan oleh Drs. Ali Nurdin, MA yang menyatakan bahwa: "Perangkat Pembelajaran seperti Program tahunan disusun berdasarkan beberapa komponen berupa satuan pendidikan, mata pelajaran, Kelas/semester, Tahun Pelajaran, Kompetensi Inti, kompetensi Dasar, dan alokasi waktu. Penetapan alokasi waktu diperlukan agar seluruh kompetensi dasar yang ada dalam kurikulum seluruhnya dapat dicapai oleh peserta didik. Sehingga program tahunan dapat menjadi tolak ukur ketercapaian seluruh belajar siswa yang terdapat dalam kurikulum". (Sumber data: Guru PAI, Tgl: 25 februari 2019).

Program semester berisikan garis-garis besar mengenai hal-hal yang hendak dilaksanakan dan dicapai dalam semester tersebut. Program semester ini merupakan penjabaran dari program tahunan. Kalau program tahunan disusun untuk menentukan jumlah jam yang diperlukan untuk mencapai kompetensi dasar, maka dalam program semester diarahkan untuk menjawab minggu keberapa atau kapan pembelajaran untuk mencapai kompetensi dasar itu dilakukan.

Sebagaimana pendapat yang dikemukakan oleh Sarmidi, S.Ag yang menyatakan bahwa: "Setiap guru pendidikan agama Islam menyusun program semester yang merupakan penjabaran dari program tahunan yang berisi hal-hal yang ingin dicapai pada semester tersebut. Program semester akan mempermudah guru dalam alokasi waktu mengajarkan materi yang harus dicapai dalam semester. Maka program semester tidak dapat disusun sebelum tersusun program tahunan". (Sumber data: Guru PAI, Tgl: 25 februari 2019).

Senada yang disampaikan oleh Siti Hadijah, S.Pd.I menyatakan bahwa: "Penyusunan program semester adalah rangkaian dari perangkat pembelajaran yang wajib dimiliki oleh seorang guru, Komponen Program semester berupa: Satuan pendidikan, mata pelajaran, kelas/semester, Tahun Pelajaran, Kompetensi Dasar, Materi pokok, Jumlah jam pelajaran, dan minggu efektif dalam satu bulan.". (Sumber data: Guru PAI, Tgl: 4 maret 2019).

Rencana Pelaksanaan Pembelajaran (RPP) Pendidikan Agama Islam pada hakekatnya bila suatu kegiatan direncanakan lebih dahulu, maka 
tujuan dari kegiatan akan terarah dan efektif. Itulah sebabnya seorang guru pendidikan Agama Islam harus memiliki kemampuan ekstra dan memiliki keterampilan yang handal dalam merencanakan program pembelajaran, seorang guru pendidikan agama Islam sebelum mengajar hendaknya merencanakan program pembelajaran, membuat persiapan pembelajaran oleh akan diberikan kepada peserta didik.

Sesuai hasil wawancara yang diperoleh Dra. Risma Wahyuni, MA mengatakan bahwa: "Tugas guru sebelum mengajar adalah membuat Rencana Pelaksanaan pembelajaran (RPP) yang harus dibuat dengan ditanda tangani oleh kepala sekolah sebagai bukti kita sudah siap melaksanakan pembelajaran. RPP dirancang untuk mencapai tujuan pembelajaran karena di RPP itu terdapat langkah-langkah pembelajaran. Jadi RPP harus dibuat sebagai rancangan atau gambaran terhadap semua kegiatan pembelajaran yaitu tentang apa saja akan dilakukan ketika masuk kelas sampai keluar kelas". (Sumber data: Kepala Sekolah, Tgl: 22 Februari 2019).

Berdasarkan uraian di atas, dapat dipahami bahwa tugas semua guru termasuk guru Pendidikan Agama Islam sebelum mengajar harus membuat perencanaan pembelajaran yang tersusun di dalam RPP sebagai aplikasi keberhasilan pembelajaran baik ranah kognitif, afektif dan psikomotorik peserta didik. Hal ini bertujuan agar guru PAI dapat melaksanakan tugasnya dengan baik. Guru PAI memiliki peran penting sebagai guru yang diguguh dan ditiru oleh peserta didiknya. Oleh sebab itu, guru PAI harus merencanakan kegiatan pembelajaran agar terlaksananya perangkat pembelajaran dengan baik.

Rencana Pelaksanaan Pembelajaran (RPP) merupakan salah satu perangkat pembelajaran yang dapat menentukan keberhasilan pembelajaran di SMP Negeri 1 Percut Sei tuan. Namun permasalahannya, apakah semua guru Pendidikan agama Islam telah memiliki Komponenkomponen Rencana Pelaksanaan Pembelajaran (RPP) yang sesuai dengan Permendikbud No.22 Tahun 2016.

Berdasarkan hasil Analisis bahwa persiapan yang dilakukan guru dalam membuat Perangkat Pembelajaran Pendidikan agama Islam berdasarkan kurikulum 2013 sudah termasuk sangat baik. Pendapat guru tentang perangkat pembelajaran berbeda-beda, Namun meskipun berbeda tetapi masih ada persamaan pendapat tentang perangkat pembelajaran, diantaranya: Perhitungan Minggu Efektif, Program Tahunan, Program Semester, Silabus, Rencana Pelaksanaan Pembelajaran (RPP), Media Pembelajaran, Penilaian Hasil Belajar. 
Perangkat Pembelajaran yang dibahas dalam penelitian ini ada enam yaitu: Program Tahunan, Program Semester, Silabus, Rencana Pelaksanaan Pembelajaran (RPP), Media Pembelajaran, Penilaian Hasil Belajar. Namun, Peneliti hanya menganalisis Program Tahunan, Program Semester, dan Rencana Pelaksanaan Pembelajaran. karena untuk perhitungan minggu efektif sudah dicantumkan kedalam program tahunan dan program semester, sedangkan silabus sudah disusun oleh pemerintah, kemudian untuk Media pembelajaran dan penilaian hasil belajar sudah tercantum kedalam Rencana Pelaksanaan Pembelajaran (RPP).

Berdasarkan hasil Analisis tersebut diatas dapat disimpulkan bahwa dalam Penyusunan Program Tahunan, dalam mencantumkan Kompetensi Inti dan Kompetensi Dasar sudah sangat sesuai karena sudah disusun sesuai dengan silabus kurikulum 2013. Sedangkan untuk menghitung Minggu Efektif Tatap Muka, Minggu Efektif Non Tatap Muka, Minggu Non Efektif Satu Tahun sudah sesuai, karena memerlukan kejelian dalam memastikan jumlah Minggu efektif serta non efektif dalam satu tahun. Kemudian untuk Mendistribusikan Alokasi Waktu dalam satu Tahun masih kurang sesuai dan Menentukan Keluasan Materi tiap Kompetensi Dasar masih tidak sesuai karena harus mengacu pada kelender pendidikan, Materi Pembelajaran dan Kompetensi Dasar.

Penyusunan Program Semester, dalam mencantumkan Kompetensi Inti dan Kompetensi Dasar sudah sangat sesuai karena sudah disusun sesuai dengan silabus kurikulum 2013. Sedangkan untuk Menghitung Minggu Efektif Tatap Muka Semester satu dan semester dua, serta menghitung Minggu Efektif Non Tatap Muka Semester satu dan semester dua sudah sesuai. Kemudian untuk Menghitung jumlah total bulan di semester satu dan semester dua kurang sesuai, begitu pula untuk Mendistribusikan Alokasi Waktu di setiap Semester masih tidak sesuai karena harus mengacu pada kelender pendidikan dan Kompetensi Dasar.

Penyusunan Rencana Pelaksanaan Pembelajaran (RPP), untuk Kelengkapan Identitas Satuan Pelajaran, langkah-langkah pembelajaran dan Penilaian Hasil Belajar sudah sesuai dengan komponen RPP kurikulum 2013, sedangkan Indikator Pencapaian Kompetensi, Media Pembelajaran, dan Sumber Belajar, sesuai dengan komponen RPP kurikulum 2013 tetapi masih ada satu indikator yang tidak sesuai dengan kata kerja operasional, dan sumber belajar perlu dilengkapi sumber buku lain sebagai pelengkap. Untuk Materi pembelajaran masih kurang sesuai dengan komponen RPP kurikulum 2013 karena tidak memuat fakta, 
konsep, prinsip, dan prosedur yang relevan, Materi Pembelajaran hanya mencantumkan pokok-pokoknya saja. Kemudian untuk Perumusan Tujuan Pembelajaran dan Metode Pembelajaran tidak sesuai dengan komponen RPP kurikulum 2013 karena tidak dicantumkan dalam komponen Rencana Pelaksanaan Pembelajaran (RPP) guru Pendidikan Agama Islam di SMP Negeri 1 Percut Sei Tuan Deli Serdang.

\section{Simpulan dan Rekomendasi}

Simpulan yang dapat ditarik sebagai berikut: (1) penyusunan Program Tahunan, dalam mencantumkan Kompetensi Inti dan Kompetensi Dasar sudah sangat sesuai karena sudah disusun sesuai dengan silabus kurikulum 2013. Sedangkan untuk menghitung Minggu Efektif Tatap Muka, Minggu Efektif Non Tatap Muka, Minggu Non Efektif Satu Tahun sudah sesuai, karena memerlukan kejelian dalam memastikan jumlah Minggu efektif serta non efektif dalam satu tahun. Kemudian untuk Mendistribusikan Alokasi Waktu dalam satu Tahun masih kurang sesuai dan Menentukan Keluasan Materi tiap Kompetensi Dasar masih tidak sesuai karena harus mengacu pada kelender pendidikan, Materi Pembelajaran dan Kompetensi Dasar, (2) penyusunan Program Semester, dalam mencantumkan Kompetensi Inti dan Kompetensi Dasar sudah sangat sesuai karena sudah disusun sesuai dengan silabus kurikulum 2013. Sedangkan untuk Menghitung Minggu Efektif Tatap Muka Semester satu dan semester dua, serta menghitung Minggu Efektif Non Tatap Muka Semester satu dan semester dua sudah sesuai. Kemudian untuk Menghitung jumlah total bulan di semester satu dan semester dua kurang sesuai, begitu pula untuk Mendistribusikan Alokasi Waktu di setiap Semester masih tidak sesuai karena harus mengacu pada kelender pendidikan dan Kompetensi Dasar, dan (3) penyusunan Rencana Pelaksanaan Pembelajaran (RPP), untuk Kelengkapan Identitas Satuan Pelajaran, langkah-langkah pembelajaran dan Penilaian Hasil Belajar sudah sesuai dengan komponen RPP kurikulum 2013, sedangkan Indikator Pencapaian Kompetensi, Media Pembelajaran, dan Sumber Belajar, sesuai dengan komponen RPP kurikulum 2013 tetapi masih ada satu indikator yang tidak sesuai dengan kata kerja operasional, dan sumber belajar perlu dilengkapi sumber buku lain sebagai pelengkap. Untuk Materi pembelajaran masih kurang sesuai dengan komponen RPP kurikulum 2013 karena tidak memuat fakta, konsep, prinsip, dan prosedur yang relevan, Materi Pembelajaran hanya mencantumkan pokok-pokoknya saja. Kemudian untuk Perumusan 
Tujuan Pembelajaran dan Metode Pembelajaran tidak sesuai dengan komponen RPP kurikulum 2013 karena tidak dicantumkan dalam komponen Rencana Pelaksanaan Pembelajaran (RPP) guru Pendidikan Agama Islam di SMP Negeri 1 Percut Sei Tuan Deli Serdang.

Rekomendasi yang dapat disampaikan adalah: (1) kepada Kepala Sekolah, hendaknya meningkatkan pengawasan dan perhatian terhadap perangkat pembelajaran guru, bagi guru yang kurang berkompeten agar dapat diberi kesempatan untuk mengikuti pelatihan-pelatihan, sehingga dapat meningkatkan kemampuan guru dalam menyiapkan perangkat pembelajaran, (2) kepada guru diiharapkan dapat mempersiapkan perangkat pembelajaran sebelum proses pembelajaran dimulai, Sehingga tujuan pembelajaran yang diharapkan dapat tercapai.

\section{DAFTAR PUSTAKA}

Abdul Majid, (2012). Perencanaan Pembelajaran Mengembangkan Standar Kompetensi Guru, Bandung: Remaja Rosdakarya.

Abuddin, Nata. (2012). Sejarah Pendidikan Islam. Cet. III; Jakarta: Rajawali Pers.

Ahmad D. Marimba, (2001). Pengantar Filsafat Pendidikan Islam. Cet. XV; Bandung: Al-Ma'arif.

Antonius, (2016). Buku Pedoman Guru .Cet.II. Bandung: Yrama Widya.

Asep Jihad dan Abdul Haris, (2008). Evaluasi Pembelajaran .Yogyakarta: Multi Presindo.

Athiyah al-Absyari, (1984). Dasar-dasar Pokok Pendidikan Islam, Ter. Bustami A. Gani dkk.Jakarta: Bulan Bintang.

Daryanto, (2014). Pendekatan Pembelajaran Saintifik Kurikulum 2013, Cet. I; Yogyakarta: Gava Media.

Departemen Pendidikan Nasional. (2005). Kamus Besar Bahasa Indonesia edisi ketiga Balai Pustaka, Jakarta.

Hasan Langgulung, (1987). Asas-asas Pendidikan Islam .Cet.I; Jakarta: Pustaka Al-Husnah.

Kamus Besar Bahasa Indonesia, (2007). Cet. III; Jakarta: Pustaka Karya. Kunandar, (2013) Penilaian autentik (Penilaian Hasil Belajar Peserta Didik Bersarkan Kurikulum2013).Cet. II; Jakarta: Raja Grafindo Persada. Muhaimin, (2004). Wacana Pendidikan Islam .Cet. II; Surabaya: PSAMPM. Mulyasa, (2006). Menjadi Guru Profesional: Menciptakan Pembelajarann Kreatif dan Menyenangkan .Cet. III; Bandung: Remaja Rosdakarya. 